\title{
Technical Characteristics of Muscovy Duck (Cairina moschata) in Ciayumajakuning, West Java Indonesia
}

\author{
D. Widianingrum ${ }^{1,2^{*}}$, T. Widjastuti ${ }^{3}$, A. Anang ${ }^{3}$ and I. Setiawan ${ }^{3}$
}

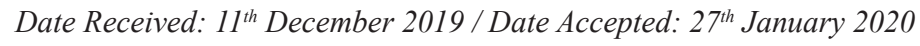

\begin{abstract}
Purpose : This research aims to study the technical characteristics of Muscovy duck in Ciayumajakuning.

Research Method: The study uses a survey method and applies a purposive sampling to take samples by observing 22 farmers. Data analysis used in this study is a descriptive exploratory method.

Findings : The results show that $95.5 \%$ of pens are in postal shape; $50 \%$ of the pen material is made from bamboo, wood, and roof tile while the other $50 \%$ is made from bamboo and roof tile; $72.7 \%$ of observed farmers have size of pens of 1-100; 95.5\% of feed is in pasta-shaped and $4.5 \%$ is in flour; the frequency of 2 times feeding is $86.4 \%$; mostly-used (54.5\%) feed ingredient is in the form of Aking rice bran and $18.2 \%$ use pur bran; $9.1 \%$ farmers apply traditional raising management, $81.8 \%$ is semiintensive, and $9.1 \%$ is intensive; lastly, sex ratio of 1: 1 reaches $18.2 \%$. Conclusion that the technical characteristics of Muscovy duck in Ciayumajakuning have not yet been standardized. It is expected that the farmers, relevant agencies, and other related parties can overcome the problem and seek for better and optimal management.
\end{abstract}

Limitations : Research includes feed, pen, and raising management of Muscovy Duck.

Value: The basis for establishing national standards for Muscovy Duck production and development.

Keywords: Technical Charasteristic, Muscovy duck, Ciayumajakuning

\section{INTRODUCTION}

Muscovy duck (Cairina moschata) is one of the waterfowls commonly raised in Indonesia. Muscovy duck has a high potential as a source of animal protein and can be used for meat and eggs production, and therefore, more attention has been agreed lately on increasing meat production, especially ducks which are considered the easiest domestic poultry (ElSoukkary et al,2005). African Muscovy duck weight (12 weeks) drake weighed $1832 \mathrm{~g}$, while the fedrake reached only $68.2 \%$ of the drake weight (Téguia et al, 2008). In term of body size, Muscovy duck is generally larger than broilers and laying ducks so that it has the potential as livestock of a meat producer. (Ali, 2005) showed that average dressing percentage was 62.18 in Muscovy ducks. (El-Samee et al, 2012) dressing percentage, being 73.35 in Muscovy duck at the same age 12 week.
Muscovy Generally; Indonesian people raise Muscovy duck for meat and as savings that can be sold anytime when they are in need.

Muscovy duck population in West Java is $1,451,743$. The Muscovy duck population in the regencies of Cirebon, Indramayu, Majalengka and Kuningan (Ciayumajakuning) is 1,036,666 head or about $71 \%$ of Muscovy duck population is in West Java (Dinas Peternakan Provinsi Jawa

\footnotetext{
Production of Livestock and Poultry of Faculty of Animal Husbandry, Padjajaran University, Jl. Raya BandungSumedang Km 21, Jatinangor-Sumedang, 45363, West Java, Indonesia.

${ }^{2 *}$ Study program of Animal Husbandry, Faculty of Agriculture, Majalengka University, Jl. KH. Abdul Halim No. 103 Majalengka 45418, West Java, Indonesia.

diniwidianingrum@unma.ac.id

3 Faculty of Animal Science, Padjadjaran University, Jl. Raya Bandung-Sumedang Km 21 Jatinangor-Sumedang, 45363, West Java, Indonesia.
}

(D) ORCID http://orcid.org/0000-0001-5619-4973 
Barat, 2017). If it is not properly raised and maintained, the Muscovy duck population will become extinct. The raising and development of Muscovy duck must be supported by high productivity.

The productivity of Muscovy duck in Ciayumajakuning is still low, which is marked by the length of time to raise them (12 weeks) before farmers can get their meat with optimum in 28 weeks is considered drake and 24 weeks duck is considered an adult. While body weight of the sudani duck (one year old) weighed 2171 with feed conversion recorded 4.4 (ElSamee,1982). Further studies were reported on Muscovy ducks in Egypt (El-Ghamry, 2014). They do the mating process naturally which causes problems in the process of reproduction and production in general. Their raising system is still traditional in nature, which means it is only a farmers' side job, the ownership scale is less than 10, breeds are passed down from generation to generation, pens are made from used materials such as bamboo and wooden crate of egg or fruits, feeding with whatever food that can be found such as the lowest level of rice bran and waste vegetables, farmers let the Muscovy duck to roam freely (extensive), and there is no prevention and treatment of the disease so that the Muscovy duck could have died suddenly and causing losses to farmers.

Muscovy duck productivity can be increased through the use of superior breeds supported by good feeding and raising management. Excellent Muscovy duck breeds can be obtained by selection, namely the decision to choose Muscovy ducks with superior characteristics to be kept alive. Muscovy duck characteristics consist of biological and technical features. Biological characteristics include qualitative and quantitative properties. Qualitative traits are properties visible to the eye that can be used as trademarks, such as the color of plumage, beak shapes, and shank colors. Quantitative traits are properties with high economic value that are not visible to the eye but can be measured, such as body weight, beak length, neck length, wing length, body length, femur length, tibia length and shank length. Technical characteristics include pen, feed, and raising management.

The pen consists of shape, material, and size. Poultry production in Europe is based mainly on intensive systems (Damaziak et al, 2014). Raising management, intensification has enabled increased production with lower financial inputs (Erisir et al., 2019). The negative effects of this type of raising management are, however, worse product quality and deteriorating bird welfare (Mench, 1992). Ducks that are kept in intensive systems are characterized by, inter alia, many behavioral disorders that often lead to self-mutilation and cannibalism (Raud and Faure, 1994) (Zhang et al., 2009).

Feed consists of the form of food, frequency of feeding, and feed ingredients. Muscovy duck is significantly different from other ducks in the growth curve as well as body composition. Muscovy duck ration protein requirements aged 4-6 weeks around 14.5 - 15\%, body weight of 1085 grams, and consumption of 2850 grams of ration (Leclerceq et al, 1986). Protein requirements for optimal growth from period $0-3$ week around $12-18 \%$. For the tropics it is also available $24 \%$ for period of $0-8$ weeks. The content of protein rations for Muscovy duck can vary but this is related to the energy content of the ration (Dean, 2001). In the initial period, enter fed a diet containing 22\% protein, but (Siregar et al,1982) allow $18-19 \%$ with an energy of $3000 \mathrm{kcal} / \mathrm{kg}$ of ration. Energy requirements for Muscovy duck is almost the same as broiler chicken (Mohammed et al, 1984). Research results on White Pekin can also be used for Muscovy, which is $0-2$ weeks old given a ration containing $2900 \mathrm{kcal} / \mathrm{kg}$ of energy and aged 2-7 weeks given rations containing $16 \%$ protein with $3000 \mathrm{kcal} / \mathrm{kg}$ energy (National research Council, 1994). Raising management consists of the sex ratio and pen maintenance system.

Therefore, the importance of raising ducks has also increased gradually (Ensminger, 1992). Ducks are usually raised in intensive systems without pool (Selcuk and Akyurt, 1986). This system is divided into three groups; extensive, semi-intensive, and intensive. Intensive system includes deep litter and cage systems (Önk et 
al, 2018). Ducks are raised in a closed room for this system in such a way to provide proper air conditioning and ventilation as for chicken (Rodenburg, 2005).

Research on drake body size has been done by (Yakubu, 2013) in Africa which includes body weight, body length, body circumference, thigh circumference or tibia, beak length, neck length, leg length, and wing length. Muscovy duck body measurements in four districts can be used to determine the characteristics of Muscovy duck. (Fatmarischa, 2013) states that the phenotypic diversity of Muscovy ducks based on body size can determine the characteristics of Muscovy ducks in Central Java. (Fatmarischa, 2013) only examined the biological characteristics of drake and duck aged 6 months, while their technical characteristics have not been studied, even though these technical characteristics are crucial in order to get good technical standards in supporting optimal Muscovy duck productivity. This study aims to study the technical characteristics of Muscovy duck raising in Ciayumajakuning.

\section{OBJECT AND RESEARCH METHOD}

Observations are conducted on 22 Muscovy duck farmers consisting of 4 farmers from Cirebon, 4 from Indramayu, 9 from Majalengka, and 5 from Kuningan. The selection of the study area was carried out using a purposive sample based on participation data in West Java obtained from the Animal Husbandry Department of West Java Province in 2017 and the potential of dredging marketing. Sampling was conducted by multistage probability stratified random sampling multistage random sampling (Sulistyo and Basuki. 2006) based on the largest population of dents in each district based on data (Dinas Peternakan dan Kesehatan Hewan Kabupaten Indramayu, 2017) (Dinas Peternakan Provinsi Jawa Barat, 2017). This study uses a survey method with purposive sampling to select samples. Data analysis uses descriptive exploratory analysis. Primary data were obtained from observations and direct interviews with farmers. Secondary data were obtained from relevant officials and agencies.

\section{RESULT AND DISCUSSION}

\section{Scope of Ciayumajakuning Area}

Jawa Barat (West Java) Province is located at coordinates of $104^{\circ} 48^{\prime}-108^{\circ} 48^{\prime}$ East Longitude and $5^{\circ} 50^{\prime}-7^{\circ} 50^{\prime}$ South Latitude. The altitude of place can be divided into places with steep heights of more than $1500 \mathrm{~m}$ above sea level (asl) in the southern region, sloping hillside areas in the middle of 100-1500 m asl and 19$857 \mathrm{~m}$ asl, and large plateau areas in the north of $1-100 \mathrm{~m}$ above sea level. The minimum temperature is $19.5^{\circ} \mathrm{C}$ and the maximum is $29.9^{\circ} \mathrm{C}$ with the average humidity of $74 \%$. The area is $35,377.76 \mathrm{~km} 2$. Total population of 1,180,774 inhabitants. Jawa Barat consists of 18 regencies, 9 cities, sub-districts, 13 (urban) villages, and 323 villages (Badan Pusat Statistika Jawa Barat, 2017). The Muscovy duck population is $1,348,324$ head centered in the districts of Indramayu, Cirebon, Bogor and Majalengka (Dinas Peternakan Provinsi Jawa Barat, 2017).

Cirebon Regency is located at coordinates of $108^{\circ} 40^{\prime}-108^{\circ} 48^{\prime}$ East Longitude and $6^{\circ} 30^{\prime}$ $7^{\circ} 00^{\prime}$ South Latitude. The altitude is $0-300 \mathrm{~m}$ asl. Temperatures range from $25^{\circ}$ to $34^{\circ} \mathrm{C}$. The total area is $990,40 \mathrm{~km} 2$. The total population of people is 2.162.644. Cirebon consists of 40 regencies and 412 (urban) villages (Wikipedia Indonesia, 2015) (Badan Perencanaan Pembangunan, Penelitian dan Pengembangan Daerah Kabupaten Cirebon 2018). The Muscovy duck population is 253.063 centered in the districts of Celancang, Sindang Laut, and Sasak (Dinas Peternakan Provinsi Jawa Barat, 2017).

Indramayu Regency is located at coordinates of $107^{\circ} 52^{\prime}-108^{\circ} 48^{\prime}$ East Longitude and $6^{\circ}$ $15^{\prime}-6^{\circ} 40^{\prime}$ South Latitude. The altitude is $0-18$ $\mathrm{m}$ asl. Temperatures range from $24^{\circ}$ to $29^{\circ}$ C. The total area is $1.204,24 \mathrm{~km} 2$. The total population of people is 1.180 .774 . Indramayu consists of 31 regencies, 8 (urban) villages and 307 villages (Wikipedia Indonesia, 2015) (Badan Perencanaan Pembangunan, Penelitian dan Pengembangan Daerah Kabupaten Cirebon 2018). The Muscovy duck population is 770.605 centered in the districts of Losarang, Kroya, and 
Gabus Wetan (Dinas Peternakan dan Kesehatan Hewan Kabupaten Indramayu, 2017) (Dinas Peternakan Provinsi Jawa Barat, 2017).

Majalengka Regency is located at coordinates of $108^{\circ} 12^{\prime}-108^{\circ} 25^{\prime}$ East Longitude and $6^{\circ} 4^{\prime}$ $7^{\circ} 03^{\prime}$ South Latitude. The altitude is $19-857$ $\mathrm{m}$ asl. Temperatures range from $24^{\circ}$ to $34^{\circ}$ C. The total area is $1.204,24 \mathrm{~km} 2$. The total population is 1.180.774. Majalengka consists of 26 regencies, 13 (urban) villages and 323 villages (Wikipedia Indonesia, 2015) (Badan Perencanaan Pembangunan, Penelitian dan Pengembangan Daerah Kabupaten Majalengka, 2018). The Muscovy duck population is 129.980 centered in the districts of Rajagaluh, Jatiwangi, and Bantarujeg (Dinas Peternakan Provinsi Jawa Barat. 2017).

Kuningan Regency is located at coordinates of $108^{\circ} 23^{\prime}-108^{\circ} 47^{\prime}$ East Longitude and $6^{\circ} 47^{\prime}-7^{\circ}$ $12^{\prime}$ 'South Latitude. The altitude is $120-700-1500$ $\mathrm{m}$ asl. Temperatures range from $22^{\circ}$ to $29^{\circ} \mathrm{C}$. The total area is $1.178,58 \mathrm{~km} 2$. The total population is 1.140.777. Kuningan consists of 32 regencies and 376 (urban) villages (Wikipedia Indonesia, 2015)(Badan Perencanaan Pembangunan Daerah Kabupaten Kuningan, 2018). Based on a preliminary survey at 2017 the Muscovy duck population is 980 centered in the districts of Darma and Cigugur.

\section{Pen}

The following Figure 01 describes pen of Muscovy duck.

Based on Figure 01, there are $95.4 \%$ of postal-shaped Muscovy duck pens in Cirebon, Indramayu, Majalengka and Kuningan. Generally, the Muscovy duck pen has a shelter, a playground in the form of a yard and pond, and a place of feed and drink provided by farmers; but there are also pens that are already in the form of buildings $(4.6 \%)$ in intensive Muscovy duck raising in Majalengka which have proper place for play, food, and drink. The pen building is divided into 3 parts based on Muscovy duck age, namely starter (age 0-2 months), grower ( $>2-5$ months), and broodstock ( $>5$ months). Postal pens generally consist of shelters and place for play. According to (Soeharsono,
1976). playing or physical exercise to move muscles is a healthy activity. Physical motion, emotions, social growth and development are in line with the growth and development of the functions of organs in the body to support the implementation of activities in life (Hall, 1991). Increased muscle mass is not only caused by the number of muscle cells but because of the increase in myofibrils. The enlarged muscle due to exercise is not caused by the increasing number of muscle cells (hyperplation) but because of muscle volume (hypertrophy) (Soeharsono, 1976).

$50 \%$ of Muscovy duck pen materials are made from bamboo, wood, and roof tile; while the other $50 \%$ is made from bamboo and roof tile. Pens are made using materials found around farmers' houses, for example, bamboo and wood from gardens or the-used ones and only a few are deliberately purchased. Pen/pen size is generally less than $100(72.7 \%)$, the remaining are the size of100-200 (9.1\%), 300-400 (9.1\%), and 400-500 (9.1\%). Bamboo is a suitable material for pens in the tropics because it can substitute wood. The advantages of bamboo from wood, among others, are having a small shrinkage ratio, they can be bent or having elasticity, and they also have a high decorative value (Arsyad, 2015). ( Sulastiningsih and Santoso, 2012) argue that bamboo is one of the raw materials that easily split, formed, processed, with a relatively cheap price compared to the wood raw material. The availability of bamboo for pens is quite a lot, able to reduce $\mathrm{CO} 2$ emissions, and produce heat efficiency by $80 \%$ (Wang and Yan, 2005).

\section{Feed}

The following figure 02 describes Feed of Muscovy duck.

Based on figure 02 above, 95.5\% of Muscovy duck feed is a paste-shaped, which is feed material brewed or mixed with hot water then cooled briefly; after it is cold or in a warm state then it is given to Muscovy duck. Flour feed is $4.5 \%$. The shape of the ration affects its efficiency. The ration is crucial because it holds a budget of around $70 \%$ of the production costs allocation (Syamsu, 2007). 


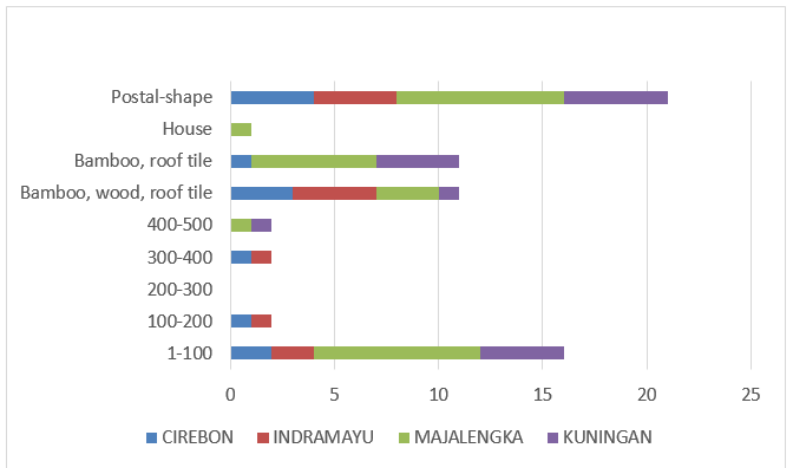

Figure 01: $\quad$ Pen of Muscovy duck

The form of commercial feed rations is generally in the form of pellets. (Murtidjo, 1987) (Cuti, 2003) added cassava flour as an adhesive to the pellet-shaped ration. Ration storage is an important element in supporting the success of livestock business (Syarief dan Halid,1993).

The frequency of feeding twice a day (86.4\%) is done in the morning and evening with consideration of time efficiency for farmers. Frequency of feeding 3 times per day (13.6\%) is done in the morning, afternoon, and evening with the consideration that the food can be consumed more than wasted. Feeding can be done by ad libitum (freestyle-feeding) and restricted feeding. Feed restriction on duck: Muscovy ducks aim to obtain uniform body weight during adult, to delay adult mating, to reduce fat before the egg-laying period, to increase egg weight by delaying adult mating, to decrease feed conversion in the growth phase, to improve the quality of hatching eggs, and to increase Muscovy duck health (Fassbinder-Orth and Karasov, 2006). Feed restriction also aims to control growth because Muscovy ducks are a type of livestock that grow fast (Ayuningtiyas, 2016).

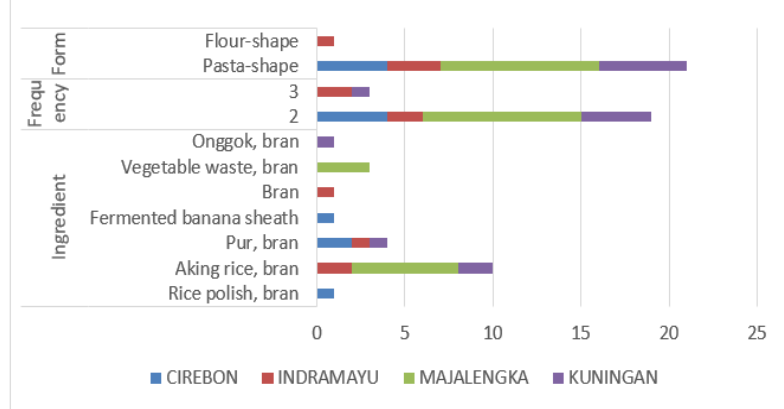

Figure 02: $\quad$ Feed of Muscovy duck

Feed of Muscovy duck: $50 \%$ use the Aking rice bran, $18.2 \%$ use pur bran, $13.6 \%$ use vegetable waste bran, $4.5 \%$ use rice bran, $4.5 \%$ use banana sheath bran, $4.5 \%$ use onggok bran, and $4.5 \%$ use rice polish. Farmers take feed ingredients around them with the consideration of the feed availability and price, such as vegetable waste, banana sheath/stems, and Aking rice. Some farmers even try to use alternative feed ingredients such as azolla, maggot, and indigofera but still in small quantities and frequency of administration at uncertain times. According to (El-Samee, 2012) the nutritional content of Muscovy duck rations aged 3-12 weeks contains metabolic energy of $2922 \mathrm{kcal} /$ $\mathrm{kg}$ and crude protein of $18.28 \%$ which can produce an Muscovy duck body weight of 2590.0 grams/head; body weight gain 1888.33 grams/head with feed consumption of 131.05 grams/head/day, and feed conversion of 4.7 . While in (El-Badry, 2004) Muscovy duck body weight at the same age is 3243 grams/head.

\section{Raising Management}

The following figure 03 is the Raising management of Muscovy duck.

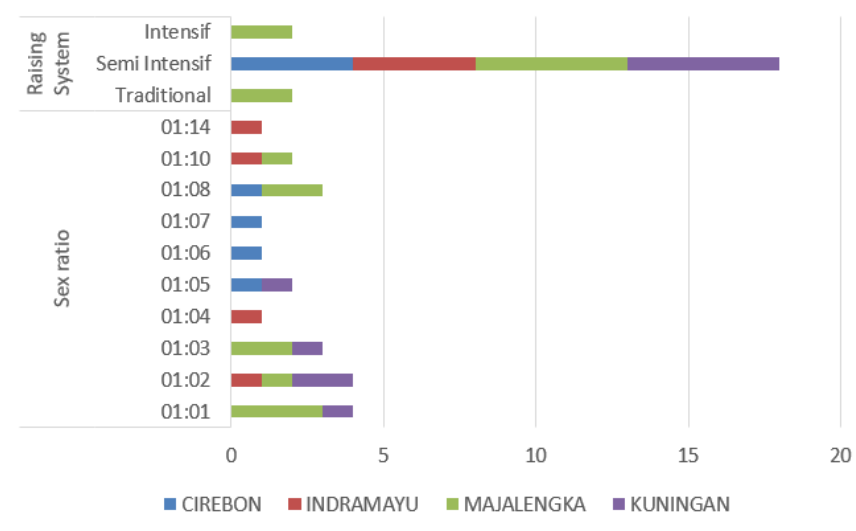

Figure 03: $\quad$ Raising Management of Muscovy duck 
Based on figure 03, raising management of intensive Muscovy duck is $9.1 \%$. This raising uses the whole pen building for Muscovy duck to carry out all its activities such as sheltering and resting, eating, drinking, reproducing, and playing. Semi intensive Muscovy duck raising is $81.8 \%$, means there is a pen for shelter and rest at night and a yard to eat, drink, reproduce, and play during the day. Traditional Muscovy duck raising reaches $9.1 \%$, with a pen for Muscovy duck to shelter and rest, but there is no divider which limits the Muscovy duck to do its activities. Muscovy ducks can play in the yard, fields, and even mingle around the housing. Land capacity for Muscovy ducks with a roam freely raising system is 2500 or 5000 per hectare in an intensively managed yard. The density of pens for Muscovy ducks with conventional raising system in Germany is 9 heads/m2 (non litre), intensive is 5 heads/ $\mathrm{m} 2$; whereas, conventional animal raising in France is 13 animals/m2, intensive is 9 animals/ $\mathrm{m} 2$ (Rodenburg et al, 20015). The size of pond for Muscovy duck raising is $30 \mathrm{~m}$ long, $10 \mathrm{~m}$ wide and $3 \mathrm{~m}$ deep. The best swimming time for Muscovy duck is between 12.00-14.00 which can improve its performance, the carcass percentage, tenderness, and body temperature (Farghly, 2017). In summer, the duration of Muscovy duck playing in the yard is 4 hours to improve its performance, carcass percentage, tenderness, and body temperature (Farghly, 2018)

Sex ratio of $1: 1(18,2 \%), 1: 2(18,2 \%), 1: 3$ $(13,6 \%), 1: 8(13,6 \%), 1: 5(9,1 \%), 1: 4(4,5 \%)$, $1: 6(4,5 \%), 1: 7(4,5 \%)$, and $1: 11(4,5 \%)$. Sex ratio affects the fertility and hatchability of eggs. Fertility is the ratio between the number of fertile eggs and hatched eggs. Hatchability is the ratio between the number of eggs that hatch with fertile eggs. (According and Roudybush, 1971), the optimal sex ratio for ducks is at 1 : 5. This was confirmed by (Nickolova, 2010) study which stated that an Muscovy duck sex ratio of 1: 5 produced the highest fertility at peak production times of $98.4 \%, 1: 6$ produced
96.2\% fertility, and 1: 7 produced $95.95 \%$ fertility.

\section{CONCLUSION}

Based on result and discussion, it can be concluded that the technical characteristics of Muscovy duck in Ciayumajakuning have not yet been standardized. It is supported by the following data that $95.5 \%$ of Muscovy duck pens are in postal shape; $50 \%$ of the pen material is made from bamboo, wood, and roof tile while the other $50 \%$ is made from bamboo and roof tile; $72.7 \%$ of observed farmers have size of pens of $1-100 ; 95.5 \%$ of Muscovy duck feed is in pasta-shaped and $4.5 \%$ is in flour; the frequency of 2 times feeding in the morning and evening is $86.4 \%$; mostly-used (54.5\%) feed ingredient is in the form of Aking rice bran and $18.2 \%$ use pur bran; $9.1 \%$ farmers apply traditional raising management, $81.8 \%$ is semiintensive, and $9.1 \%$ is intensive; lastly, sex ratio of 1 : 1 reaches $18.2 \%$.

\section{Data Availability Statement}

The datasets generated during and/or analyzed during the current study are available from the corresponding author on reasonable request.

\section{ACKNOWLEDGMENT}

The author would like to thank and extend the highest appreciation to all those who have helped in this research, especially to the Ministry of Research and Technology that has provided scholarships for postgraduate education providers (BPPDN), Muscovy duck Farmers in Ciayumajakuning, the Dean and the Academic Community of the Faculty of Animal Husbandry, Padjadjaran University, the Dean and the Civitas Academic Academic Faculty of Agriculture, Majalengka University, and ICESAT Committee.

\section{REFERENCES}

Ali, K.A.A., (2005). Studies on some factors affecting duck production. Ph.D thesis, Fac. Agric., Cairo Univ. 
Arsyad, I., (2015). Teknologi Pengolahan dan Manfaat Bambu. Balai Riset dan Standarsisasi Industri Banjarbaru. Jurnal Riset Industri Hasil Hutan. Vol. 7 No. 2 Juli 2015. DOI: https:// doi.org/10.24111/jrihh.v7i1.856

Ayuningtiyas, G., Jakaria, Rukmiasih, dan C. Budiman, (2016). Produktivitas Muscovy duck Betinadengan Pemberian Pakan Terbatas, selama Periode Pertumbuhan. Jurnal Ilmu Produksi dan Teknologi Hasil Peternakan. ISSN 2303-2227. Vol. 04 No. 2 Juni 2016. Hlm. 280-285. DOI: https://doi.org/10.29244/jipthp.4.2.280-285

Badan Perencanaan Pembangunan Daerah Kabupaten Kuningan (Bappeda), (2018). Rencana Pembangunan Jangka Menengah Daerah. https://bappeda.jabarprov.go.id DOI: https://doi. org/10.34010/komputa.v4i1.2403

Badan Perencanaan Pembangunan, Penelitian dan Pengembangan Daerah Kabupaten Indramayu (Bappeda), (2018). Rencana Pembangunan Jangka Menengah Daerah. https:// bappedaindramayu.madebychocaholic.com DOI: https://doi.org/10.34010/komputa. v4i1.2403

Badan Perencanaan Pembangunan, Penelitian dan Pengembangan Daerah Kabupaten Cirebon (Bappeda), (2018). Rencana Pembangunan Jangka Menengah Daerah. https://bappeda. cirebonkab.go.id DOI: https://doi.org/10.34010/komputa.v4i1.2403

Badan Perencanaan Pembangunan, Penelitian dan Pengembangan Daerah (Bappelitbangda) Kabupaten Majalengka, (2018). Rencana Pembangunan Jangka Menengah Daerah. https:// bappeda.majalengkakab.go.id DOI: https://doi.org/10.34010/komputa.v4i1.2403

BPS (Badan Pusat Statistika) Jawa Barat. (2017). Provinsi Jawa Barat dalam Angka. BPS Jawa Barat. DOI: https://doi.org/10.36805/bi.v1i2.132

Cuti, S., (2003). Penambahan Tepung Gaplek sebagai Perekat terhadap Sifat Fisik Ransum Ayam Broiler Bentuk Pellet. Program Studi Ilmu Nutrisi dan Makanan Ternak. Fakultas Pertanian Bogor. DOI: https://doi.org/10.6066/jtip.2018.29.1.58

Damaziak, K., M. Michalczuk, D. Adamek, M. Czapliński, J. Niemiec, A. Goryl \& D. Pietrzak. (2014). Influence of housing system on the growth and histological structure of duck muscles. South African Journal of Animal Science, 44 (No. 2). DOI: https://doi.org/10.4314/sajas. v44i2.1

Dean, (2001). Nutrient Requirement of meat - Type ducks dalam Duck production Science and world Practise. Printed and Published by the University of New England, armilade.

Dinas Peternakan dan Kesehatan Hewan Kabupaten Indramayu Jawa Barat. (2017). Populasi Itik Manila di Kabupaten Indramayu. https://dinaskeswan.indramayukab.go.id DOI: https://doi. org/10.36973/jkih.v5i2.46

Dinas Peternakan Provinsi Jawa Barat. (2017). Populasi Itik Manila di Jawa Barat. Bandung. https://jabarprov.go.id

El-Badry, A.S.O., (2004). Effect of early heat exposure and feeding system on physiological response and productive performanceof duckling under heat stress conditions.Ph.D Thesis, Fac. Agric., Cairo Egypt. 
El-Ghamry, A.A., H.M. Azouz and A.T. Elyamny, (2004). Effect of hot pepper and seeds supplementation to low energy diets on Muscovey ducklings performance. Egypt. Poult. Sci., 24: 613-627.

El-Samee, L.D.A, (1982). Studies on preservation of duck meat. M.Sc. thesis, Fac. Agric., Cairo Univ.

El-Samee, L.D.A., Hewida M.H. El-Allawy and Nagwa A. Maghraby. (2012). Comparative Study on Some Productive Traits of Muscovy and Sudani Ducks in Egypt. International Journal of Poultry Science 11 (4): 264-268. DOI: https://doi.org/10.3923/ijps.2012.264.268

El-Soukkary, F.A.H., H.M.A. Mohamed, A.A.A. Dawood and S.Y. Abd-El Sayed, (2005). Physicochemical, microbiological and lipid characteristics of duck meat. Minufiya J. Agric. Res., 30: $527-548$.

Ensminger, M. E. (1992). Poultry sciences. 3rd ed. Interstate Publishers, Danville, Illinois

Erisir, Z., Poyraz, O. Onbasilar, E.E. Erdem, E. \& Kandemir, O., (2009). Effect of different housing systems on growth and welfare of Pekin Ducks. J. Anim. Vet. Adv. 8, 235-239.

Farghly, M.F., K. Mahrose, Z. Ullah, Z.U. Rehman. (2017). Influence Swimming Time in Alleviating the Deleterious Effects of Hot Summer on Growong Muscovy Duck Performance. Poultry Science Journal 96 (11) Agustus. DOI: https://doi.org/10.3382/ps/pex207

Farghly, M.F., U. Mahmoud. (2018). Access to outdoor swimming pond during summer seasonimproved Muscovy ducks performance and health status. Journal Livestock Science Journal 211 Maret. DOI: https://doi.org/10.1016/j.livsci.2018.03.008

Fassbinder-Orth, C.A. dan W.H. Karasov. (2006). Effect of feed restricted and realimentation on digestive and immune function in the leghorn chick. Intern J. Poultry Sci. 85: 1449-1456. DOI: https://doi.org/10.1093/ps/85.8.1449

Fatmarischa, N., Sutopo, dan S. Johari. (2013). Ukuran Tubuh Entok di Tiga Kabupaten Provinsi Jawa Tengah. Sains Peternakan ISSN 1693-8828. Vol. 11 (2) : 106-112. DOI: https://doi. org/10.20961/sainspet.11.2.106-112

Hall, DA. (1991). The Biomedicak Basis of Grontogy. W.B. Saunders Company. Harcovert Brace Jopvanovich Inc.

Leclerceq, B., Dan H. De. Carville. (1986). Dietary energy, Protein and Phosphorus Requirements of Muscovy Ducks . Printed and Published by the University of New England, armilade.

Mench, J.A., (1992). The welfare of poultry in modern production systems. Poult. Sci. Rev. 4, 107-128.

Mohammed, K., B. Leclercq, A. Anar, H. El-Alaily, dan H. Solaiman. (1984). A Comparative Study of Metabolisable energy in Duclings and Domestic Chicks. Anim Feed Seri, Technol, 11:199. DOI: https://doi.org/10.1016/0377-8401(84)90063-4

Murtidjo, B.A., (1987). Pedoman Meramu Pakan Unggas. Kanisius. Yogyakarta.

National research Council, (1994). Nutrient Requirement of Poultry.NinthRevised Edition. Printing and Publishing. National academy of Science Washington. 
Nickolova, M. (2010). Effect of The Sex Ratio on the Egg Fertility Of Muscovy Duck (Cairina Moshcata). Journal Centre European Agriculture. Volume 5 (2004) No. 4 (367-372).

Önk, Kadir, Mehmet Sarı, Ismayil Safa Gürcan, Serpil Adıgüzel Işık. (2018). Live weight and body measurements of male and female native ducks raised in different raising systems. Brazilian Journal of Animal Science ISSN 1806-9290. 47:e20170084, 2018 DOI: https://doi. org/10.1590/rbz4720170084

Raud, H. \& Faure, J.M., (1994). Welfare of ducks in intensive units. Revue Scientifique et Technique (International Office of Epizootics) 13, 119-129. DOI: https://doi.org/10.20506/rst.13.1.752

Rodenburg, B., M.B.M. Bracke, J. Berk,., J. Cooper, (2005). Welfare of Ducks in European Duck Husbandry Systems. World's Poultry Science Journal 61 (4). DOI: https://doi.org/10.1079/ wps 200575

Rodenburg, T. B.; Bracke, M. B. M.; Berk, J.; Cooper, J.; Faure, J. M.; Guemene, D.; Guy, G.; Harlander, A.; Jones, T.; Knierim, U.; Kuhnt, K.; Pingel, H.; Reiter, K.; Serviere, J. and Ruis, M. A. W. (2005). Welfare of ducks in European duck husbandry systems. World's Poultry Science Journal 61:633-646. DOI: https://doi.org/10.1079/wps200575

Selcuk, E. and Akyurt, I. (1986). Duck husbandry. Ministry of Agriculture and Forest press, No. 8 , Ankara, Turkey.

Siregar, A.P., R.B. Cumming, dan D.J. Farrel. (1982). The Nutrition of meat Type Ducks. 1. The Effect of Dietary Protein in Isoenergetic Diets on Biological Performance. Austr.J. Agric. Res. 33:857. DOI: https://doi.org/10.1071/ar9820857

Soeharsono. (1976). Respon Broiler terhadap Berbagai Kondisi Lingkungan. Disertasi. Universitas Padjadjaran, Bandung.

Sulastiningsih, I.M. dan Santoso, A , (2012). Pengaruh Jenis Bambu Waktu Kempa dan Perlakuan Pendahuluan Bilah Bambu terhadap Sifat Papan Bambu Lamina. Jurnal Penelitian Hasil Hutan 30 (3), 198-206. DOI: https://doi.org/10.20886/jphh.2012.30.3.199-207

Sulistyo and Basuki. (2006). Metode Penelitian. Wedatama Widya Sastra. Fakultas Ilmu Pengetahuan Budaya Universitas Indonesia. ISBN 979-3258-51-9. Jakarta.

Syamsu, J.A., (2007). Karakteristik Fisik Pakan Itik Bentuk Pellet yang diberi Bahan Perekat Berbeda dan Lama Penyimpanan Berbeda. Jurnal Ilmu Ternak, Desember 2007. Vol. 7 No. 2, 128-134. DOI: https://doi.org/10.24014/jupet.v13i1.2387

Syarief, R and Halid, H., (1993). Teknologi Penyimpanan Pangan. Kerjasama dengan Pusat Antar Universitas Pangan dan Gizi IPB. Penerbit Arcan. Jakarta.

Téguia, A., H. M. Ngandjou, H. Defang, J. Tchoumboue. (2008). Study of the live body weight and body characteristics of the African Muscovy duck (Cairina moschata). Trop. Anim. Health. Prod. 40:5-10. DOI: https://doi.org/10.1007/s11250-007-9030-4

Vohra and Roudybush. (1971). The effect of various level dietary protein on growth and egg production of coturnix coturnix japonica. Poultry Science. 50:1081-1084. DOI: https://doi. org/10.3382/ps.0501081

Wang and Yan, (2005). Feasibility Analysis Wood Pellets Production and Utilization in China as a Substitute for Coal. International Journal Green Energy. DOI: https://doi.org/10.1081/ge200051313 
Wikipedia Indonesia, (2015). Provinsi Jawa Barat, Kabupaten Cirebon. https://id.m.wikipedia.org

Yakubu, A. (2013). Characterisation of the local Muscovy duck in Nigeria and its potential for egg and meat production. World's Poultry Science Journal69: 931-938. DOI: https://doi. org/10.1017/s0043933913000937

Zhang, J.E., Xu, R. Chen, X. \& Quan, G., (2009). Effects of duck activities and a weed community undera transplanted rice-duck farming system in southern China. Weed Biol. Manag. 9, 250257. DOI: https://doi.org/10.1111/j.1445-6664.2009.00346.x 